\title{
DERIVATIONAL AND INFLECTIONAL MORPHEME ANALYSIS ON THE SONG LYRICS OF LADY GAGA "A STAR IS BORN" ALBUM
}

\author{
Ira Nur Aprianti ${ }^{1}$, Aseptiana Parmawati ${ }^{2}$ \\ ${ }^{1}$ IKIP Siliwangi \\ ${ }^{2}$ IKIP Siliwangi \\ ${ }^{1}$ Iranur.april@gmail.com, ${ }^{2}$ aseptiamaparmawati@gmail.com
}

\begin{abstract}
The tittle of this research is Affixes Analysis on the Song Lyrics of Lady Gaga "A Star is Born" Album. The method that used in this study is to analyst the lyrics of "A Star is Born" album and the technique that used to collect the data is analyzing technique that used is qualitative method. The purpose of this research is to identify and find out the farms of the affix of derivation and inflectional from the lyrics of "A Star is Born" album. Based on the analysis, it was found that many types of derivation and inflectional affix. The most dominant that found in the Lady Gaga album song is derivation affix. The result of this research, 14 data or $58,3 \%$ derivation affixes 10 data or $41,7 \% \%$ that inflectional found in "A Stars is Born" album.
\end{abstract}

Keywords: Morphology, Affixes, Derivational, Inflectional

\section{INTRODUCTION}

Language is the tool of human to communicate and interact with others human. It means that language is the way of human to express or delivering the massage. Language is needed to be understood what the goals it is going to be and to convey ideas and information through oral or written. language itself is able to be learnt and studied by brace of science, it is called linguistic. According to Bauer (2012:3) as cited in (Yastanti \& Warlina, 2018) "linguistics is the word meaning 'relating to language' as well as word meaning 'relating to linguistics'. In other word, linguistics and language will not be able to separate because linguistics is a part of language, they have connection so closer between them. Linguistics is a scientific of language which has pattern including morphology, syntax, phonetics, phonology, semantics and pragmatics.

Word is the basic foundation that should be exist in language cause without word the sentence will not came out to be used. In linguistic, words are able to be learnt about how the complications of word forms and the effect of changes in word forms on word groups and meaning, and it is called morphology. According to Hamawand $(2011$, p.2) as cited in (Meinawati \& Alawiyah, 2018) "morphology is the study how words are built of form-meaning units" "morphology is essential subfield of linguistics". Another definition comes from Haspelmarth and Sims (2010:18) as cited in (Suherman et al., 2018) "morphology as the study of internal structure of words" whereas Booij (2008) as cited in (Suherman et al., 2018) claims that morphology as the grammar of words. Based on the definitions above they have several similar ideas of morphology that it is as branch of linguistic that the purposes are to analyze about the structure of words and studies about the meaning of elements every word. Words elements or morphemes is a based word or the smallest word of linguistics that has a lot of 
meaning. Morpheme is a part of language that has many functions to build the word and sentences. Based on (Orchidiani et al., 2018) the way of the forming new word in appending the morpheme to e words is referred to as affixation. It is divided two kind of morpheme those are free and bound morpheme.

For the first is free morpheme. It is the elements of word that can stand alone as a word without any smallest word beside to help as one meaning. This word is usually called unbound morpheme. Further, bound morpheme is revers to free morpheme that the word is independent. Bound morpheme needs other words beside to stand as one word in one meaning. There are two kinds of bound morpheme, they are derivational morpheme and inflectional morpheme.

Derivational morpheme is the process of the word formation that has a function to build a new word then change a new meaning and word class. It has two position of affixes in a word those are prefix and suffixation. Procter (1980:15) as cited in (Putri, 2018)says that "affix could be a group of letters or sound added to beginning of a word or the top of the word". Therefore, affixes are because the smallest word that added in beginning or ending. In beginning of word, it's called prefix while ending of word is named suffix. Nikelas.S \& Mahadwipa in (Luh \& Hendrayani, 2018) inflectional morpheme has several characteristics including the meaning of part of speech is not changing through the morpheme, they show the connection of syntactic or semantic in different words of a sentence, all members of typically is occurred, they typically occur at the margin of words. It can be concluded that inflection is the process of appending affixes to the root or base which do not change the class of word in the most refined speech level in certain language. In other terms, inflectional morpheme is the word formation that the combining between free morpheme and bound morpheme without any changing the word. The position of inflection affix is always suffix.

There are several functions of language such as artistic, practical, philosophical, science and technology. In artistic people can product the language itself such as in the song. So many people like a song. Song is part of music that consist of many lyrics and melody some time the contents of the song is a poem or the massage that delivered by the musician about what they are feeling which intending to be a sung.

The writer was interested to analyze the linguistics form of lyrics' song because song the way people to express their feeling through the lyrics' song and it is able to be found so many linguistics' sense. Affixes is always found in many aspects such as in article, books, magazine, newspaper, movie, scrip and lyrics' song. The writer chooses lyrics as an object of the study and focused on analyzing the affixes of derivational and inflectional because the writer like singing a song. The song that chosen is from the famous singer in Hollywood she is lady gaga. She was an eccentric singer and talented in playing movie. "A Star is Born" was the titled of movie that she played and also contented united of her albums. The songs were a soundtrack of the movie in 2018 years ago. The album is chosen by the author because the object study.. There are two songs entitled "shallow" and "always remember us this way". The researcher interested to conducted the study entitled Derivational and Inflectional Morpheme Analysis on the Song Lyrics of Lady Gaga "A Star is Born” Album.

\section{METHOD}

The study of this research is about the analysis, where in getting the information of data is using qualitative descriptive. The qualitative design is an approach for exploring and understanding from something happening of social or human problem. Based on to Airisian as cited in (Rezeki 
\& Rakhmat, 2019) descriptive qualitative research is the method of collecting data in answering the question concerning the current statues of the subject of the study.According to Wardah \& Subiyanto (2019)" There are three stages which the writers use in this study, namely (1) collecting data; (2) analyzing data; and (3) concluding data". In collecting the data, the writer gained it from the album song lyrics entitle, "shallow" and "always remember us this way" and the information that is gained to help in process analyzing the linguistics form especially morpheme was searching from some reference such as from internet and books. The first step that the writer conducted was searching the data of a affix that would be analyzed on the album song lyrics entitle, "shallow" and "always remember us this way". And the last step was selecting and analyzing the data of a affix which word that include derivation or inflectional morpheme.

\section{RESULTS AND DISCUSSION}

\section{Results}

The data of this research was from a star is born' album song entitle , "shallow" and "always remember us this way. There are many affixes in this article so the data are taken to identify and analyzed which word that are formed derivation or inflectional morpheme.

Table 1. The kinds of derivational morpheme "always remember us this way"

\begin{tabular}{|c|c|c|c|c|c|}
\hline \multirow{2}{*}{ Morpheme } & \multirow{2}{*}{ Word } & \multicolumn{2}{|c|}{ Types of affixes } & \multirow{2}{*}{ Analysis } & \multirow{2}{*}{ Line } \\
\hline & & Prefix & Suffix & & \\
\hline \multirow[t]{7}{*}{ 1. Derivational } & Choked & - & ed & $\begin{array}{c}\text { Choke (verb) } \\
\text { Choked (adjective) }\end{array}$ & 7 \\
\hline & Remember & $\operatorname{Re}$ & - & $\begin{array}{l}\text { Member (verb) } \\
\text { Remember (verb) }\end{array}$ & 11 \\
\hline & Always & $\mathrm{Al}$ & - & $\begin{array}{c}\text { Ways(noun) } \\
\text { Always (adverb) }\end{array}$ & 11 \\
\hline & Lover & - & $\mathrm{r}$ & $\begin{array}{l}\text { Love(verb) } \\
\text { Lover(noun) }\end{array}$ & 12 \\
\hline & Trying & - & Ing & $\begin{array}{c}\text { Try (verb) } \\
\text { Trying (adjective) }\end{array}$ & 13 \\
\hline & Really & - & ly & $\begin{array}{l}\text { Real(adjective) } \\
\text { Really (adverb) }\end{array}$ & 15 \\
\hline & & Mour & & & 6 \\
\hline \multirow[t]{7}{*}{ 2. Inflectional } & Burning & - & Ing & Progressive & 2 \\
\hline & Eyes & - & $\mathrm{s}$ & Plural & 2 \\
\hline & Buried & - & ed & Passive & 4 \\
\hline & Words & - & $\mathrm{s}$ & Plural & 7 \\
\hline & Hurts & - & $\mathrm{s}$ & Present tense & 8 \\
\hline & Goes & - & es & $\begin{array}{l}\text { Singular person } \\
\text { Present tense }\end{array}$ & 9 \\
\hline & Fades & - & s & $\begin{array}{l}\text { 3Singular person } \\
\text { Present tense }\end{array}$ & 19 \\
\hline
\end{tabular}


Based on the table above, it found of affixes which is divided by two, they are suffix and prefix. Suffix include - s,-es-r ,-in g,-ed ,ly while prefix include re -,and al - Every word has different function depend on the morpheme that found : those are derivation and inflectional. Based on the analysis above, deviation morpheme includes 6 words whereas inflectional morpheme is obtained 7 words means that derivation morpheme has many words than inflectional morpheme.

Table 2. The kinds of derivational morpheme "shallow"

\begin{tabular}{|c|c|c|c|c|c|}
\hline \multirow[t]{2}{*}{ Morpheme } & \multirow[t]{2}{*}{ Word } & \multicolumn{2}{|c|}{$\begin{array}{l}\text { Types of } \\
\text { affixes }\end{array}$} & \multirow[t]{2}{*}{ Analysis } & \multirow[t]{2}{*}{ Line } \\
\hline & & Prefix & Suffix & & \\
\hline \multirow[t]{9}{*}{$\begin{array}{l}\text { 1. } \\
\text { Derivational }\end{array}$} & Something & - & Ing & $\begin{array}{c}\text { Thing (noun) } \\
\text { Something(adverb) }\end{array}$ & 1 \\
\hline & Modern & - & $\mathrm{Rn}$ & $\begin{array}{c}\text { Mode (noun) } \\
\text { Modern (adjective) }\end{array}$ & 2 \\
\hline & Longing & - & Ing & $\begin{array}{l}\text { Long (verb) } \\
\text { Longing (noun) }\end{array}$ & 7 \\
\hline & Tired & - & Ed & $\begin{array}{c}\text { Tier (noun) } \\
\text { Tired (adjective) }\end{array}$ & 9 \\
\hline & Trying & - & Ing & $\begin{array}{c}\text { Try (verb) } \\
\text { Trying (adjective) }\end{array}$ & 9 \\
\hline & Keeping & - & Ing & $\begin{array}{r}\text { Keep (verb) } \\
\text { Keeping (noun) }\end{array}$ & 11 \\
\hline & Hardcore & Hard & - & $\begin{array}{l}\text { Core (verb) } \\
\text { Hardcore } \\
\text { (adjective) }\end{array}$ & 11 \\
\hline & Surface & Sur & - & $\begin{array}{c}\text { Face (verb) } \\
\text { Surface (noun) }\end{array}$ & 14 \\
\hline & & Mount & & & 8 \\
\hline \multirow[t]{3}{*}{ 2. Inflection } & Falling & - & Ing & Progressive & 6 \\
\hline & Searching & - & Ing & Progressive & 4 \\
\hline & Times & - & $\mathrm{s}$ & Plural & 7 \\
\hline
\end{tabular}

From the tabel.2, it can be seen that Suffixes is found more than prefix including -ing.-ed,-rn, -s for suffix while prefix include hard-,sur-, There are 9 word in suffix and 3 word in prefix. Every word that has been analyzed it can be obtained that which morpheme is. based on the result from the table above derivational were 8 word while inflectional morpheme were 3 words. Thus, the analysis of the "shallow" song can be showed that derivational had more words than inflection which has similarity with the "always remember us this way" song. 


\begin{tabular}{lllll}
\hline No. & Form of Morpheme & A Mount & Line & Percentage \\
\hline 1 & Derivational & 14 & $7,11,11,12,13,15$ & $58,3 \%$ \\
& & & $1,2,7,9,9,11,11,14$ & \\
2 & Inflectional & 10 & $2,2,4,7,8,9,19$, & $41,7 \%$ \\
& & & & \\
& & & & \\
& & & & $100 \%$
\end{tabular}

From the table 1, it can be seen that lyrics song in "A star is born" Album. The table showing that classified of derivational and inflectional morpheme in the song lyrics. Type of morpheme that dominate in this album is derivational morpheme which fifty-eight-point three percent or seventy data belonging. on the other hands, the inflectional on the album is smaller than derivational which only forty-one-point seven percent or thirteen data belonging.

\section{Discussion}

The researcher finds the reveals various of affix, and also functions of derivation and inflectional that happen on "A star is born"album. Affixes that found on the album those are suffix and prefix. Suffix is the position of affixes in behind of the base word or root. Meanwhile, prefix is the position of affix which in front of the base word or root word.

The type of suffix that are found -s, -es -r, -in g,-ed, -l y.- d.-Rn or 8 words have different function in every word depend on the sentence and context. The first is noun farming. It exist if the other parts of speech such as verb word and adjective changing become noun by adding - ing, -r, ed, -d suffix. It change the meaning or called by derivation morpheme while verb or noun added suffix $-\mathrm{s}$ behind it will change as a plural or the meaning will not change. That is called inflection. In knowing the function of those suffix will assist the reader in understanding the meaning of song lyric. In other hand, that is prefix. Usually prefix is never changing the class word of root, butt it is added to making a new word with the similar class word and also different meaning. And the writer found a base on the table above, those are -re, -al, -hard, -sur or 4 words. In prefix is always as the derivation morpheme because the word that adding by prefix in front always change the meaning.

Based on the result that had been analyzed, the research found in Lady Gaga album song lyrics e entitled "A star is born"that obtain of inflectional and derivation morpheme. The suffixes consist 7 words on the album song of Lady Gaga and it found 5 type of derivation affix and 4 types of inflectional affix. Here, they are discussed by researcher that found in Lady Gaga's song lyrics.

1. Types of inflection affixes
a. Types of number
The result show there are 3 words that found which adding -s after the root word.
Those are 'eyes', 'words' and 'times' which as a category of noun plural.
b. Types of tense 
The first is present tense that found on the song. that adding -es/-s .it found 3 words consist 'goes', 'hurts' and 'fades' that indicate third singular person and also did not change the word meaning and class.

Then is Progressive tense that adding V-ing. The result shows there are 3 words: those are 'burning', 'falling', and 'searching' and they indicate as progressive. It means that representing an action ongoing process in the now time. they did not change the word meaning or class

c. Types of voice

This is as a form of sentences in which the subject of the sentences receives action, not talking action and as a category of inflection in allowing different noun phrase to be focused on the sentence. It is commonly as past participant the result that found $\mathrm{d}$ on the song was 1 word which adding -ed after the root or base word. The word is 'buried' and indicate as the passive voice. It did not change the word meaning and class.

2. Type of derivational affixes

a. The type of affixes as a noun to adjective

The result shows that two words on this album consist, 'modern', and 'tired'. They are adjective contain derivation affix as noun to adjective. The root or base word is from noun, 'mode' and 'tire'. Both have different meaning word and class

b. The type of affixes as a verb to noun

The result shows that three words on this album consist lover', 'longing', and 'surface'. They are noun contain derivation affix as verb to noun. The root or base word is from noun 'love', 'long' and 'face'. They have different meaning word and class

c. The type of affixes as a noun to adverb

The result shows that two words on this album Always consists', 'something' 'thing'. They are adverb contain derivation affix as noun to adverb. The root or base words is from noun 'ways' and 'thin g'. Both have different meaning word and class

d. The type of affixes as a verb to adjective

The result shows that three words on this album consist 'Cooked', 'trying', 'hardcore'. They are adjective contain derivation affix as verb an adjective. The root or base word from noun, 'Cooke', 'try', and 'core'. They have different meaning word and class

e. The type of affixes as an adjective to adverb

The result shows that a word on this album consist, 'really'. It is adverb contain derivation affix as an adjective to adverb. The root or base word from noun $\mathrm{s}$ 'rea 1'. Both of them has different meaning word and class

f. The type of affixes as a verb to verb

The result shows that a word on this album consist 'Remember'. It is verb contain derivational affix as verb to verb. The root or base word from noun, 'member'. Both have different meaning word and class.

\section{CONCLUSION}

This study is concerned with the morphological of linguistics analysis of inflectional and derivational used in Lady Gaga's album song lyrics entitled "A Stars is Born". From the 
previous analysis that had been done in one week, it can be concluded that forms of Affixes were found on the lyrics song of A stars is born' album. The kinds of affixes are derivational affix and inflectional affix. There are 14 data or 58,3\% derivational affixes 10 data or $41,7 \% \%$ that inflectional found in "A Stars is Born" album. The most dominant that used on the album is derivational morpheme.

\section{ACKNOWLEDGMENTS}

First of all, we would like to thank to Allah SWT, who has given us mercies and blessing so we can finish conducting this research as good as well. And also, we would like to say thanks to all beloved friends and family who always support and motivate us during conducting this research. The researchers realize that this study is far from perfect but hopefully it can be useful to all the student who need as references.

\section{REFERENCES}

Luh, N., \& Hendrayani, S. (2018). Affixation of Nusa Penida (Bunga Mekar Vilage) Dialect: A Descriptive Study. Jurusan Pendidikan Bahasa Inggris Universitas Pendidikan Ganesha Singaraja, 5(11), 1-9.

Meinawati, E., \& Alawiyah, S. (2018). Affixation in the Script Song Lyric "Hall of Fame." Research and Innovation in Language Learning, 1(2), 89. https://doi.org/10.33603/rill.v1i2.1108

Orchidiani, A. P. ., Budasi, I., \& Kusuma, I. P. (2018). Penelitian deskriptif kualitatif ini bertujuan untuk mendeskripsikan awalan dan akhiran pada dialek Tiyingtali BTD ) yang termasuk derivasi dan infleksi . Dua narasumber dari BTD dipilih berdasarkan ruang lingkup: keluarga, kekerabatan, dan tetangga . Jurnal Pendidikan Bahasa Inggris Undiksha, 5(2)., 5(2), 1-8.

Putri, surya A. (2018). Derivational Affixes on Song Lyrics in Justin Bieber's Purpose Album Thesis. Doctoral Dissertation, UIN Sunan Ampel Surabaya).

Rezeki, I. T., \& Rakhmat, S. W. (2019). a Morphological Analysis of Derivational My . Jurnal Serunai Ilmu Pendidikan, 5(2).

Suherman, R., Indrayani, L. M., \& Krisnawati, E. (2018). Inflectional Words and Their Processes in English Children Stories. Elite : English and Literature Journal, 5(1), 1-11. https://doi.org/10.24252/elite.v5i1a1

Wardah, N., \& Subiyanto, A. (2019). Morphophonemic Analysis on Postpositional Affixes in Kamano Language of Papua New Guinea: An Item and Process Approach. PAROLE: Journal of Linguistics and Education, 9(2), 90-100. https://doi.org/10.14710/parole.v9i2.

Yastanti, U., \& Warlina, W. (2018). Affixes in Song Lyrics of Adele. IJOLTL: Indonesian Journal of Language Teaching and Linguistics, 3(1), 65-88. https://doi.org/10.30957/ijoltl.v3i1.405 